\title{
EFFECT OF COPPER ELEMENT ON HOT BEHAVIOR OF 304L STAINLESS STEEL
}

\author{
VPLIV BAKRA NA OBNAŠANJE NERJAVNEGA JEKLA 304L MED \\ VROČO DEFORMACIJO
}

\author{
Juan Li ${ }^{1,3}$, Guanghui Zhao ${ }^{1,2,3}$, Lifeng Ma ${ }^{1,2,3 *}$, Huiqin Chen ${ }^{1}$, Huaying Li ${ }^{1,2,3}$, Wei Zhang ${ }^{4}$ \\ ${ }^{1}$ Taiyuan University of Science and Technology, no. 66 Liuliu Road, Wanbailin District, Taiyuan 030024, Shanxi, China \\ ${ }^{2}$ Shanxi Provincial Key Laboratory of Metallurgical Device Design Theory and Technology \\ ${ }^{3}$ Coordinative Innovation Center of Taiyuan Heavy Machinery Equipment \\ ${ }^{4}$ Taiyuan Iron and Steel Group Co., Ltd. \\ *mlf060913@163.com
}

Prejem rokopisa - received: 2017-12-14; sprejem za objavo - accepted for publication: 2018-02-22

doi: $10.17222 / \mathrm{mit} .2017 .216$

\begin{abstract}
Hot-deformation behavior of the 304L stainless steel containing copper was investigated with compression experiments at temperatures ranging from $1173 \mathrm{~K}$ to $1423 \mathrm{~K}$ under strain rates of $0.01-20 \mathrm{~s}^{-1}$ up to the true strain of 0.69 . The adiabatic heating analysis indicated that the addition of copper to 304L resulted in a temperature rise, which was found to be sensitive to the strain rate. By calculating the constitutive equation, the hot-deformation activation energy of the non-Cu-containing steel was found to be $409 \mathrm{~kJ} / \mathrm{mol}$, but it reduced to $376 \mathrm{~kJ} / \mathrm{mol}$ when $2.42 \%$ copper was added to the steel, which implied that the addition of copper to stainless steel was not conducive to the occurrence of dynamic recrystallization. Furthermore, the true stress-strain curves indicated that the dynamic-recrystallization temperature and strain rate of the $2.42 \% \mathrm{Cu}-304 \mathrm{~L}$ steel decreased. The processing maps showed that the unstable region increased and the hot-working area became narrower. The instability region was dominated by the adiabatic-shear zone and local-flow instability. Moreover, the morphological changes of $\delta$-ferrite into coarse columnar crystals made the steel more prone to cracking.
\end{abstract}

Keywords: Cu-bearing austenitic stainless steel, constitutive equation, processing map, microstructure

Avtorji v članku opisujejo raziskavo obnašanja nerjavnega jekla, ki vsebuje baker, med vročo deformacijo. Preizkuse so izvajali

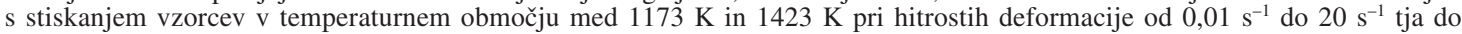
prave deformacije 0,69. Adiabatna termična analiza je pokazala, da je dodatek bakra jeklu 304L povzročil dvig temperature, $\mathrm{s}$ tem pa se je povečala občutljivost na hitrost deformacije jekla. S pomočjo konstitutivnih enačb so izračunali aktivacijsko energijo vroče deformacije jekla, ki vsebuje baker. Ta se je v primerjavi z jeklom brez vsebnosti bakra $(409 \mathrm{~kJ} / \mathrm{mol}) \mathrm{zmanjšala}$ na $376 \mathrm{~kJ} / \mathrm{mol}$ pri jeklu, ki je vsebovalo 2,42 \% bakra. To nakazuje na to, da dodatek bakra nerjavnim jeklom te vrste ne pospešuje pojava dinamične rekristalizacije. Nadalje so krivulje prava napetost-prava deformacija pokazale, da sta temperatura dinamične rekristalizacije in hitrost deformacije nižji pri nerjavnem jeklu 304L z dodatkom 2,42 \% bakra. Procesne mape kažejo, da postane optimalno (dovoljeno) področje vroče deformacije ožje. Področje nestabilnosti je kontrolirano $\mathrm{z}$ adiabatno strižno cono in lokalno nestabilnostjo plastičnega tečenja. Poleg tega je postalo jeklo zaradi morfoloških sprememb $\delta$-ferita y grobe stebričaste kristale bolj nagnjeno h krhkosti oziroma k tvorbi razpok.

Ključne besede: ležajno austenitno nerjavno jeklo na osnovi $\mathrm{Cu}$, konstitutivne enačbe, procesne mape, mikrostruktura

\section{INTRODUCTION}

The addition of copper to steel helps improve the weldability, formability and corrosion resistance, raising mechanical properties of some steels, and also makes the steel with antibacterial properties. ${ }^{1-2}$ Copper is usually added to steel as a trace element, but the amount of copper in high-copper steels can reach up to 1.4-1.5\%. At present, several studies are focused on weathering steel, high-strength steel, antibacterial steel and coppercontaining steel/steel composites. ${ }^{3-5}$ However, when the amount of added $\mathrm{Cu}$ exceeds $0.35 \%(w / \%)$ and the hot-deformation temperature is higher than $1356 \mathrm{~K}$, the liquid copper is enriched, and it then corrodes and infiltrates along the grain boundaries. It was reported that the strength of the steel reduces and the critical temperature of hot brittle cracking gradually increases, which can cause slab, edge and surface cracking, ${ }^{6-8}$ thus decreasing the product completion rate. The hot work- ability and the quality of the product are severely affected. In addition, the formation of coarse columnar grains in the as-cast steel refinement during rolling processes became a challenge for the manufacturing of high-quality products. Also, the softening behavior of as-cast materials is significantly more sluggish than that of forged steels. ${ }^{9}$ The flow curves of the as-cast Mn18Cr18N indicate monotonic work hardening. ${ }^{10}$

In this study, the hot-deformation behavior of the ascast 304L austenitic stainless steel and $2.42 \% \mathrm{Cu}-304 \mathrm{~L}$ steel were investigated with compression test. The constitutive equation for the production process was developed to evaluate the activation energy. The processing maps for the hot deformation were analyzed and the microstructure was correlated with different domains. Furthermore, the effect of the $\mathrm{Cu}$ elements added into the stainless steel on hot brittle cracking was further discussed. 
Table 1: Chemical compositions of test steel samples $(w / \%)$

\begin{tabular}{|c|c|c|c|c|c|c|c|c|}
\hline & $\mathrm{C}$ & $\mathrm{Si}$ & $\mathrm{Mn}$ & $\mathrm{P}$ & $\mathrm{S}$ & $\mathrm{Cr}$ & $\mathrm{Ni}$ & $\mathrm{Cu}$ \\
\hline $304 \mathrm{~L}$ & 0.005 & 0.42 & 1.51 & 0.004 & 0.001 & 17.88 & 8.58 & - \\
\hline $2.42 \% \mathrm{Cu}-304 \mathrm{~L}$ & 0.007 & 0.42 & 1.53 & 0.010 & 0.001 & 18.29 & 8.70 & 2.42 \\
\hline
\end{tabular}

\section{EXPERIMENTAL PART}

The materials in this study are electroslag-remelted 304L stainless-steel ingots with no copper and with $2.42 \%$ copper (by mass). The chemical compositions are presented in Table 1. The initial microstructures of the two as-cast materials are shown in Figure 1. Figure 1a shows that the $304 \mathrm{~L}$ morphology of $\delta$-ferrite is complex. The lathy ferrite and small amounts of vermicular ferrite that form during solidification are distributed in coarse columnar grains. When the $\mathrm{Cu}$ content of the 304 steel increases to $2.42 \%$ of mass fractions, the microstructure shows that the lathy ferrite is reduced and the vermicular ferrite is embedded in the austenite, which is consistent with previous reports, ${ }^{11}$ as shown in Figure $\mathbf{1 b}$.

Cylindrical specimens with a 10-mm diameter and 15 -mm height were machined from an ingot. The hot-deformation experiments were performed on Gleeble-3800. The specimens were preheated to $1523 \mathrm{~K}$ at $10 \mathrm{~K} / \mathrm{s}$ and homogenized at this temperature for $5 \mathrm{~min}$. Subsequently, the specimens were cooled, at the rate of
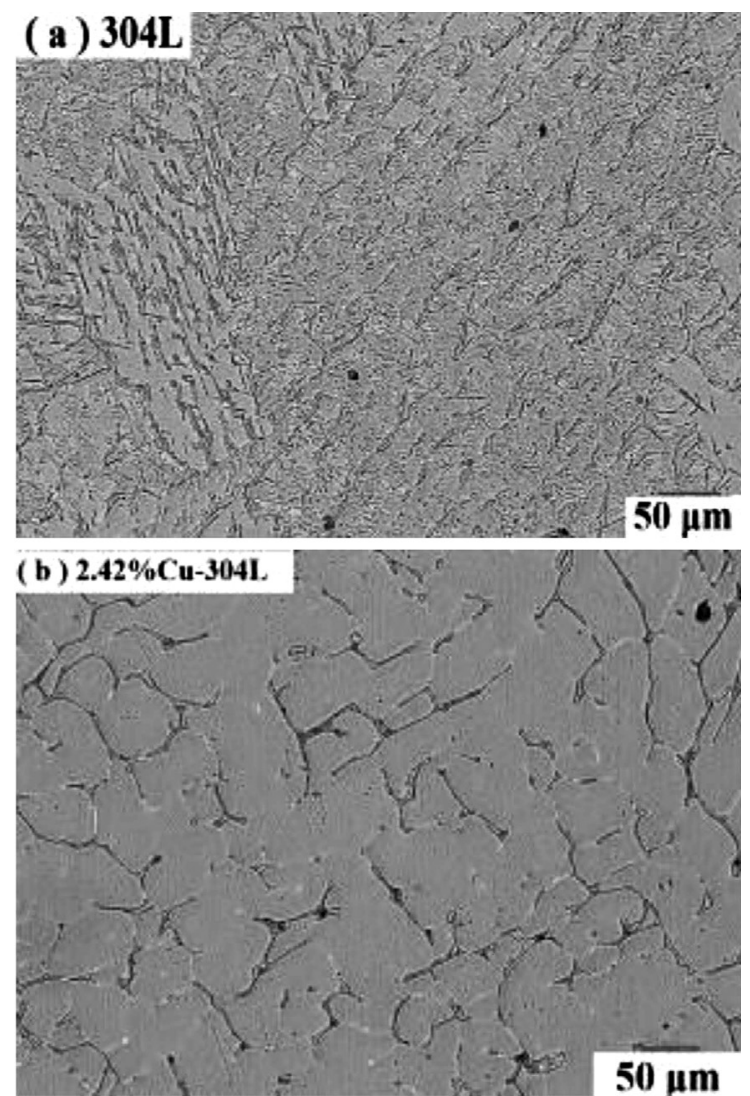

Figure 1: Original structures of as-cast steels: a) 304L, b) $2.42 \% \mathrm{Cu}-304 \mathrm{~L}$
$283 \mathrm{~K} / \mathrm{s}$, to the desired deformation temperature in a range of $1446-1423 \mathrm{~K}$ (50-K steps), and deformed at constant strain rates of $(0.01,0.1,1,2.5,5,10$ and 20$) \mathrm{s}^{-1}$ to a target true strain of 0.69 . After the compression, the specimens were immediately quenched using water to freeze the microstructure.

The compressed samples were sectioned along the central axis and prepared by following the standard metallographic procedures. The sectioned samples were etched with $10-\%$ oxalic acid for a Zeiss-optical-microscope observation. The specimen cracked for an electron-backscatter-diffraction analysis was electrolytically polished using a perchloric acid-alcohol solution at $10 \mathrm{~V}$ for $30 \mathrm{~s}$ at room temperature. Electron-backscatter-diffraction tests were performed using a ZEISS Ultra-55 field-emission scanning electron microscope. The step size for the electron-backscatter-diffraction scan was $2 \mu \mathrm{m}$.

\section{RESULTS}

\subsection{Thermal effect due to deformation heating}

The plastic deformation at higher strain rates can be transformed into heat in a short time to cause a temperature increase in the deformed material, resulting in errors in the measured values. Equation (1) is commonly used to describe the adiabatic-temperature rise $(\Delta T)$ caused by deformation ${ }^{12}$ where $\sigma$ is the flow stress, $\varepsilon$ is the true strain, and $\rho$ is the material density $\left(7.93 \mathrm{~g} / \mathrm{m}^{3}\right)$. The specific calorific value $C_{\mathrm{p}}$ was selected according to the previous finding from report ${ }^{10}$ and $\eta$ corresponds to the thermal efficiency, calculated with Equation (2): ${ }^{13}$

$$
\begin{gathered}
\Delta T=\frac{0.95 \eta}{\rho C_{\mathrm{p}}} \int_{0}^{\varepsilon} \sigma \mathrm{d} \varepsilon \\
\eta=(0.316) \lg \dot{\varepsilon}+0.95
\end{gathered}
$$
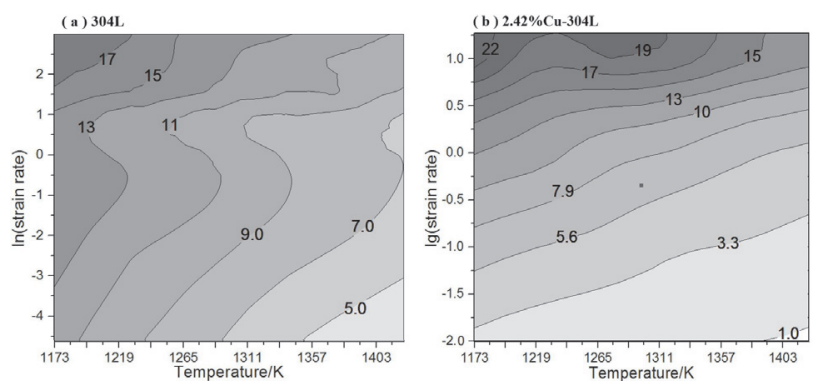

Figure 2: Temperature-rise contour plot at a strain of 0.69 as a function of compression temperature and strain rate: a) $304 \mathrm{~L}$, b) $2.42 \%$ $\mathrm{Cu}-304 \mathrm{~L}$ 
Figure 2 shows the temperature rise at different rates and temperatures at a strain of 0.69 . It can be seen that the temperature rise increases with the increasing strain rate and the decreasing deformation temperature. The maximum value of the temperature rise is observed at a high temperature and low strain rate. The effects of the temperature and strain rate on the temperature rise are similar for the $304 \mathrm{~L}$ steel, but the temperature rise for $2.42 \% \mathrm{Cu}-304 \mathrm{~L}$ is more sensitive to the strain rate. The higher thermal effect of the two kinds of steel implies that the flow-stress curves at the strain rates exceeding $1 \mathrm{~s}^{-1}$ need to be corrected.

\subsection{True stress-strain curves}

Typical true stress-strain curves for the two as-cast 304L austenitic stainless-steel samples at different deformation temperatures and strain rates are shown in Figure 3. At a constant strain rate, the peak stress increases with the decrease in the temperature due to the rapidly moving atoms at higher deformation temperatures. However, the dynamic recovery and dynamic recrystallization occur in a short period of time at higher rates, and the flow stress increases with the increasing strain rate. Macroscopically, the flow curves are characterized by work hardening at the beginning of the deformation process because of the increasing dislocation density. Dislocations were rearranged to a certain extent to form subgrains, which led to a slow dislocation-density increase, while the dynamic recovery was enhanced. As illustrated in Figure 3a, the peaking in the stress-strain curves of $304 \mathrm{~L}$ under the strain rate of $0.01 \mathrm{~s}^{-1}$ indicates the dynamic-recrystallization softening behavior. At the same strain rate (Figure $\mathbf{3 b}$ ), the stress-strain curve of the $2.42 \% \mathrm{Cu}-304 \mathrm{~L}$ steel shows that the peak value appears when the temperature is above $1273 \mathrm{~K}$. Below $1273 \mathrm{~K}$, the stress-strain curve shows typical hardening. Also, the initial yield stress is lower than the corresponding stress of the 304L steel. Figures 3c and 3d show the true stress-strain curves obtained after the correction, relating to an adiabatic temperature rise at the strain rates higher than $1 \mathrm{~s}^{-1}$. They are dynamic recovery curves without obvious peaks for the two steels, indicating that similar hot behaviors occur for the two kinds of steel at high strain rates.

\subsection{Constitutive equation of hot deformation}

Hot deformation is primarily controlled by the strain rate, temperature, strain, and thermal activation energy of the material. The Arrhenius equation modified by the hyperbolic-sine law that is commonly used, ${ }^{14}$ Equation (3), was proposed to describe a wider range of the flow stress:

$$
\dot{\varepsilon}=A[\sinh (\alpha \sigma)]^{n} \exp \left(\frac{-Q}{R T}\right)
$$
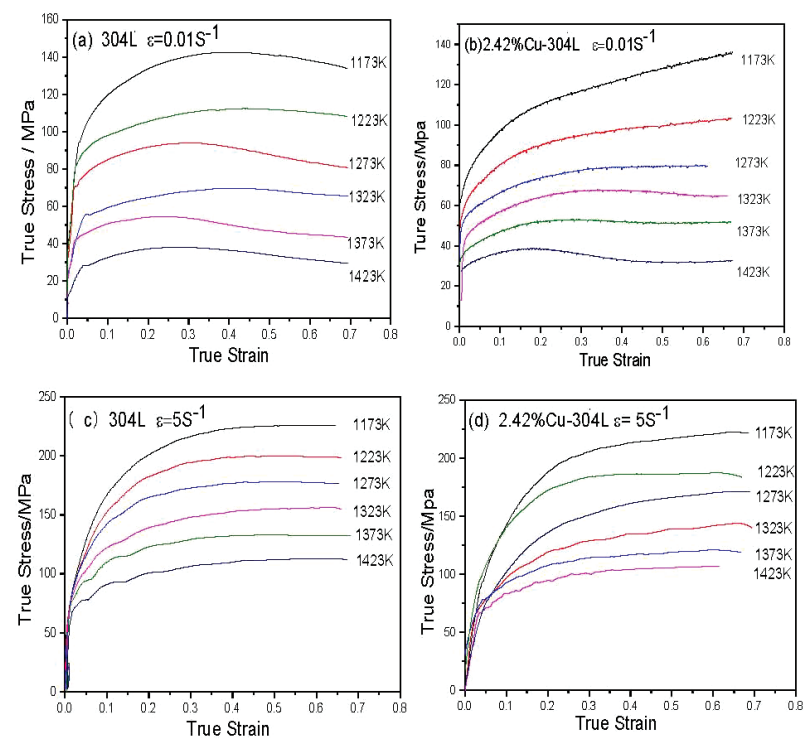

Figure 3: True stress-strain curves for the two kinds of steel at different strain rates

where $R$ is the gas constant $(8.314 \mathrm{~J} / \mathrm{mol} \cdot \mathrm{K}) ; T$ is the absolute temperature $(\mathrm{K}) ; Q$ stands for the hot-deformation activation energy $(\mathrm{kJ} / \mathrm{mol})$, which depends on the microstructure during the equilibrium state of hardening and dynamic softening; $n$ represents the stress exponent; and $A$ is the material constant, $\mathrm{s}^{-1}$. The peak-stress values measured at different strain rates and temperatures on the stress-strain curve were linearly fitted with the least squares method. By plotting $\ln \left[\sinh \left(\alpha \sigma_{\mathrm{P}}\right)\right]$ versus $\ln \dot{\varepsilon}$ and $1 / T$, respectively, the average slope of the linear regression line was obtained. It can be seen that the peak stress of the two steels increases with the decrease in the temperature (Figures $\mathbf{4 a}, \mathbf{4 d})$. The peak stress of the fitting line increases with the decrease in the strain rate in Figures $\mathbf{4 b}, \mathbf{4} \mathbf{e}$. The Zener-Hollomon parameter $(Z)$ is a compensated strain rate factor, which corresponds to temperatures, as illustrated in Equation (4). According to Figures 4c, $\mathbf{4 f}$, the plot of $\ln \left[\sinh \left(\alpha \sigma_{\mathrm{P}}\right)\right]-\ln \mathrm{Z}$ indicates a linear increase. The constitutive model parameters of the two kinds of stainless steel are shown in Table 2.

$$
\mathrm{Z}=\dot{\varepsilon} \exp \left(\frac{Q}{R T}\right)=A[\sinh (\alpha \sigma)]^{n}
$$

Table 2: Constitutive model parameters of the two austenitic stainless steels

\begin{tabular}{|c|c|c|c|c|}
\hline & $\alpha$ & $\mathrm{n}$ & $\mathrm{Q}\left(\mathrm{kJ} \mathrm{mol}^{-1}\right)$ & $\mathrm{A}$ \\
\hline $304 \mathrm{~L}$ & 0.008 & 6.61 & 409 & $4.02 \times 10^{16}$ \\
\hline $2.42 \% \mathrm{Cu}-304 \mathrm{~L}$ & 0.009 & 5.67 & 376 & $1.55 \times 10^{15}$ \\
\hline
\end{tabular}

Therefore, the constitutive equations of the $304 \mathrm{~L}$ and $2.42 \% \mathrm{Cu}-304 \mathrm{~L}$ steels can be obtained as follows:

$$
\dot{\varepsilon}=4.02 \times 10^{16}[\sinh (0.008 \sigma)]^{6.61} \exp \left(\frac{-409}{R T}\right)
$$



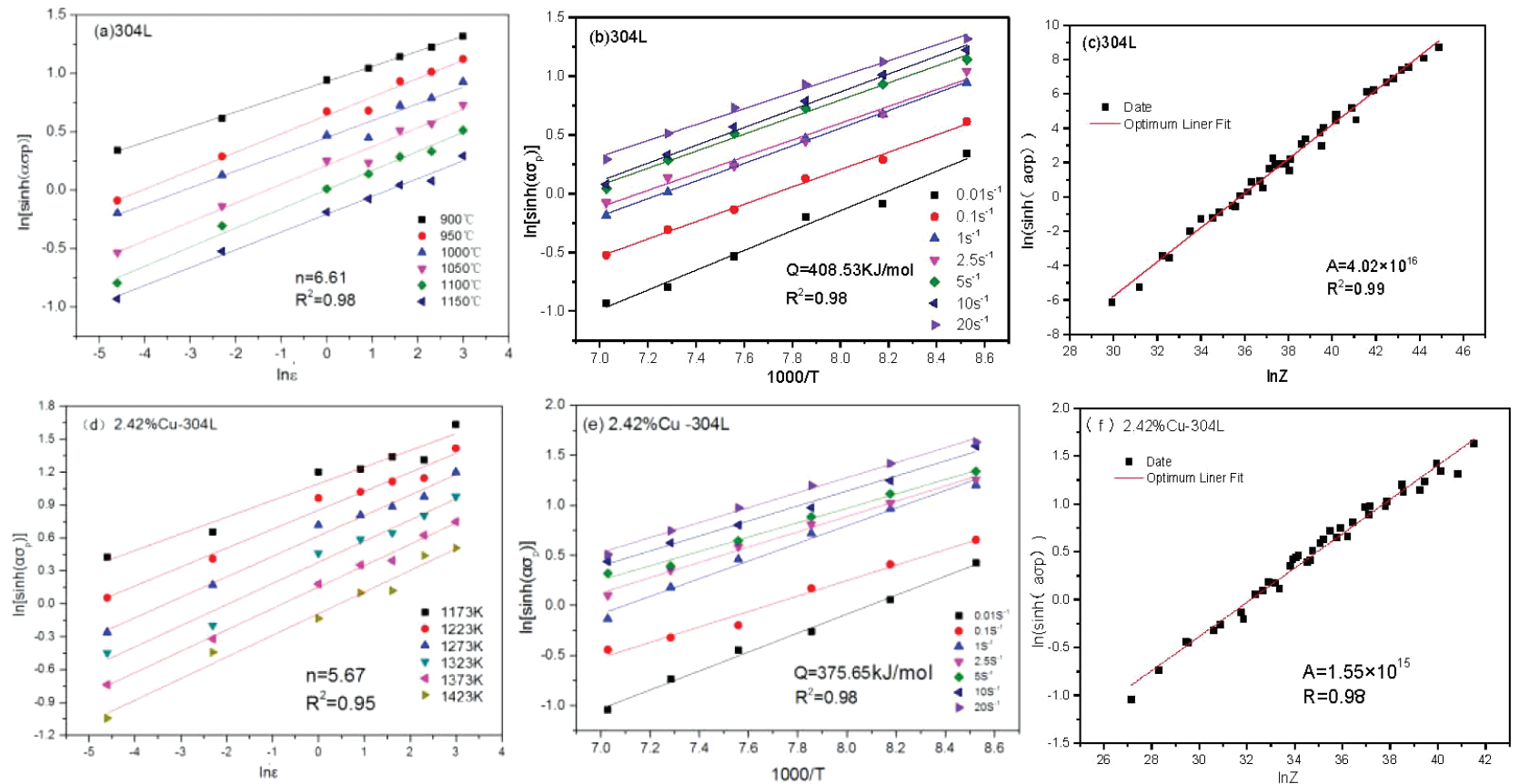

Figure 4: Evaluating the values of: a), d) n-stress exponent, b), e) Q-hot deformation activation energy, and c), f) A-material constant

$$
\dot{\varepsilon}=1.55 \times 10^{15}[\sinh (0.0089 \sigma)]^{5.67} \exp \left(\frac{-376}{R T}\right)
$$

\subsection{Processing maps}

The processing map reflects the relationship between the plastic deformation and energy dissipation, which helps to determine the suitable processing range for the material and avoid flow instability. ${ }^{15}$ Based on dynamic material modelling, the instantaneous absorbed power $P$ can be determined using the dissipation rate $G$ and dissipation covariate $J$, as shown in Equation (7). $G$ is the energy dissipated during the plastic deformation of the material, most of which is converted into heat and the rest is stored in the crystals. $J$ is the energy consumed during the evolution of the material structure, such as dynamic recrystallization, recovery, phase transition and other dissipation. ${ }^{16}$

$$
P=\sigma \cdot \dot{\varepsilon}=G+J=\int_{0}^{\dot{\varepsilon}} \sigma \mathrm{d} \dot{\varepsilon}+\int_{0}^{\sigma} \dot{\varepsilon} \mathrm{d} \sigma
$$

The logarithmic relationship between the flow stress and the strain rate at a constant temperature is described by Equation (8). The strain-rate sensitivity $m$ is the ratio of two kinds of energy. When $m=1$, the material is in the ideal linear dissipative process, as shown in Equation (9). In the process of nonlinear energy consumption, the microscopic mechanism corresponding to different deformation conditions affects the change in the dissipation covariate $J$. The non-dimensional efficiency index $\eta$ is the ratio of organizational evolution and ideal linear energy, as shown in Equation (10).

$$
\begin{gathered}
m=\frac{\mathrm{d} J}{\mathrm{~d} G}=\left\lfloor\frac{\sigma(\ln \sigma)}{\partial(\ln \dot{\varepsilon})}\right\rfloor \\
J_{\max }=\sigma \cdot \frac{\dot{\varepsilon}}{2} \\
\eta_{\text {nonlinear }}=\frac{J}{J_{\text {max }}}=\frac{2 m}{m+1}
\end{gathered}
$$

The instability criterion is given by equation $x(\dot{\varepsilon}) \leq 0$. The instability parameters of $x(\dot{\varepsilon})$ are related to the strain rate and temperature. ${ }^{17}$ Cracks, cavities, localized flow and adiabatic shear bands are prone to instability in this area.

$$
\xi(\dot{\varepsilon})=\frac{\partial \lg \left(\frac{m}{m+1}\right)}{\partial \lg \dot{\varepsilon}}+m \leq 0
$$

The results of Equation (10) were substituted into Equation (11) to determine the $\eta$ and $\xi(\dot{\varepsilon})$ of the strain rates at different temperatures with the cubic spline interpolation method. The processing maps at the true strain of 0.69 , obtained by superimposing the power dissipation map and the instability map, are shown in Figure 5. In the processing maps, the instability zones are represented by the shaded regions, and the power dissipation efficiency is represented by the contour lines. Dynamic recrystallization is more likely to occur when the $\eta$ value is higher, which improves the organization and performance. ${ }^{17}$ The general features exhibited by the processing maps for the two kinds of steel are essentially similar. The map exhibits two domains. The value of $\eta$ in domain I increases along the diagonal when the temperature increases and the strain rate decreases. The other 


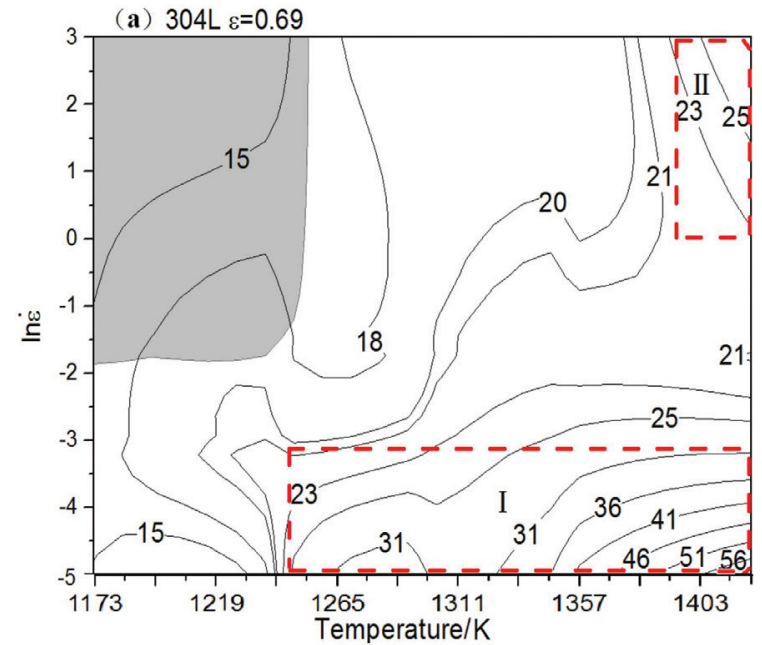

(b) $2.42 \% \mathrm{Cu}-304 \mathrm{~L} \varepsilon=0.6$

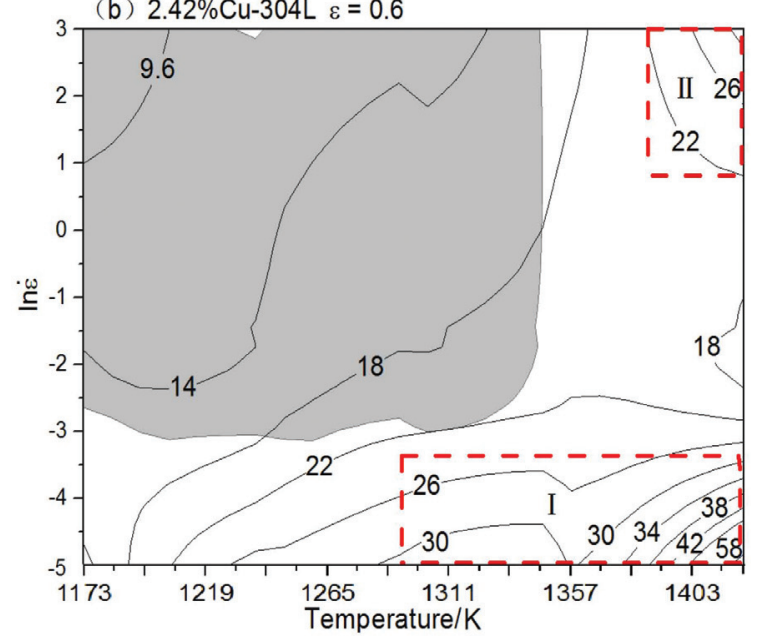

Figure 5: Processing maps of $304 \mathrm{~L}$ and $2.42 \% \mathrm{Cu}-304 \mathrm{~L}$ at the strain of 0.69 peak value of about 0.25 is observed in domain II where the strain rate is more than $1 \mathrm{~s}^{-1}$ and the temperature is above $1323 \mathrm{~K}$, and it increases with the increase in the temperatures and strain rates, which implies that dynamic recovery occurs. The unstable region appears at the lower temperature and higher strain rate. The unstable region is obviously increased and the processing range is narrowed for the 304 steel with the addition of copper. The peak efficiencies of the two kinds of steel, both above 0.5 , are observed at $1423 \mathrm{~K} / 0.001 \mathrm{~s}^{-1}$. The dynamic recrystallization region I of the $304 \mathrm{~L}$ steel, where $\eta=0.3$, is wider than that of $2.42 \% \mathrm{Cu}-304 \mathrm{~L}$.

Table 3: Optimum hot-deformation processing domain of 304L and $2.42 \% \mathrm{Cu}-304 \mathrm{~L}$

\begin{tabular}{|c|c|c|}
\hline & Temperature/K & ${\text { Strain } \text { rate } / \mathrm{s}^{-1}}^{-1}$ \\
\hline $304 \mathrm{~L}$ & $1223-1423$ & $0.01-0.1$ \\
\hline $2.42 \% \mathrm{Cu}-304 \mathrm{~L}$ & $1273-1423$ & $0.01-0.05$ \\
\hline
\end{tabular}

Generally, the thermoplasticity of austenitic stainless steel is better at $1473 \mathrm{~K}$, and gradually decreases with the decreasing temperature, and it is relatively poor at $1173 \mathrm{~K} .{ }^{18}$ Therefore, it is suggested that the processing of the two kinds of stainless steel should be performed at the optimal conditions mentioned in Table 3.

\subsection{Organization analysis in typical regions}

The microstructures of the specimens deformed in Domain I are shown in Figures $6 \mathbf{a}$ and $\mathbf{6 b}$, corresponding to the peak deformation conditions of $1423 \mathrm{~K} / 0.01 \mathrm{~s}^{-1}$. Complete dynamic recrystallization occurs in the microstructure due to the high temperature and low rate. Therefore, the hot-rolling process needs a larger
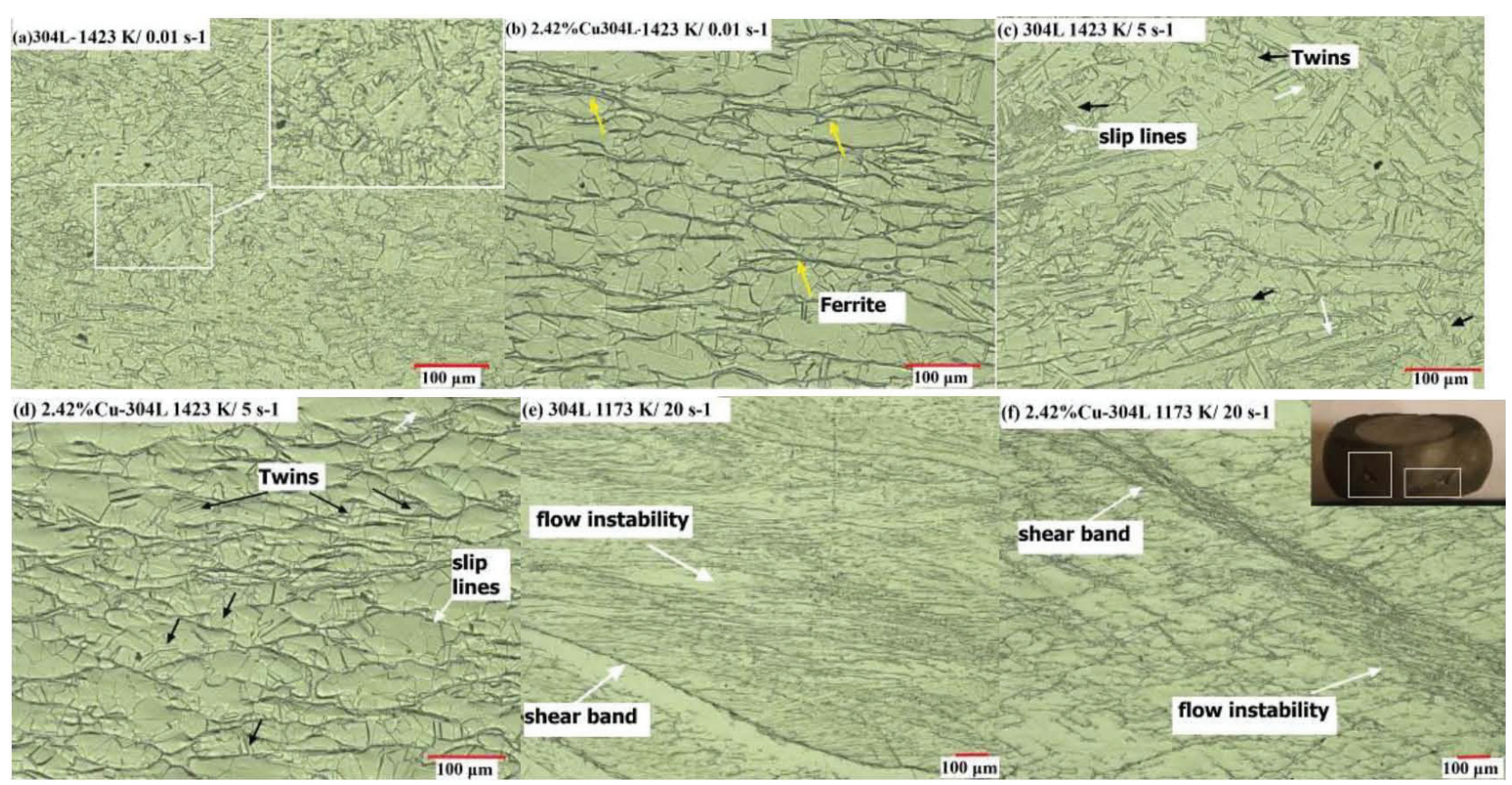

Figure 6: Microstructures in different regions of processing maps 
reduction rate to fragment the coarse cast microstructure. Comparing the microstructures of the two steels, it is found that the $2.42 \% \mathrm{Cu}-304 \mathrm{~L}$ steel has a coarse structure and a large amount of polygonal, pointed ferrite, as shown by the yellow arrows in Figure 6b. Also, the grain size of the $2.42 \% \mathrm{Cu}-304 \mathrm{~L}$ steel is larger than that of the non-Cu-containing steel.

As shown in Figures $\mathbf{6 c}$ and $\mathbf{6 d}$, elongated grains are observed at $1423 \mathrm{~K} / 5 \mathrm{~s}^{-1}$ in Domain II, which suggests that DRV and partial dynamic recrystallization take place. The dynamic-recrystallization degree increases with the increase in the temperature and strain rate. Moreover, the black arrows in Figures 6c and 6d show that the proportion of twins also increases. Both dynamic recrystallization and twins promote each other. Qin ${ }^{10}$ found that in a metal with a lower stacking-fault energy, twinning is an important dynamic-recrystallization mechanism at a high temperature and strain rate. The white arrows point out that there is a large number of slip lines parallel to each other in some grains in the 304L steel, but the increase in the number of twins in $2.42 \%$ $\mathrm{Cu}-304 \mathrm{~L}$ hinders the sliding movement and reduces the slip line. Serrated grain boundaries, the obvious localflow instability around the adiabatic shear bands in the $45^{\circ}$ direction and a lower efficiency of power dissipation indicate that the material is unstable in this region (Figures 6e, 6f). Under the same deformation conditions, a comparison between the two steels shows that the slip line is reduced in the $2.42 \% \mathrm{Cu}-304 \mathrm{~L}$ steel. Macroscopically, two $45^{\circ}$ shear cracks appear on the surface of the compressed specimen, indicating an uneven deformation.

\section{DISCUSSION}

After the solution treatment and aging, the steel with the copper content exceeding $0.75 \%$ undergoes a strengthening effect. ${ }^{18}$ However, a high content of copper can easily cause brittleness in the hot-deformation process. It is well known that heterogeneous alloys have more internal defects and form heat resistance. The final result can reduce the thermal conductivity and increase the temperature rise. ${ }^{19}$ The energy-diffusion uniformity and the slow increase in the temperature at low rates are shown in Figure 2. However, the energy in the structure increases rapidly. The addition of $\mathrm{Cu}$ to the steel leads to a deterioration of the thermal coefficient. The energy in the steel cannot be diffused, resulting in a higher temperature rise, which causes thermal softening rather than work hardening. These changes result in a local adiabatic shear band, and then an instability at high strain rates. Adiabatic shear bands are often the origin of cracks and the beginning of the material failure. The sample in Figure $6 \mathbf{f}$ indicates that a high strain rate reduces the critical deformation of specimen cracking. The cracking mode is $\mathrm{V}$ and the crack expands gradually. ${ }^{20}$
In the heating process of the as-cast stainless steel, the austenitic structure easily transforms into high-temperature ferrite. The difference between the expansion coefficients of copper and iron can cause a variation in the binding forces between two crystal atoms. ${ }^{21}$ A large volume fraction of $\delta$-ferrite causes two-phase cracking in the hot deformation, thus affecting the product completion rate. Hyejin Song ${ }^{22}$ reported that $\mathrm{Cu}$ basically raised the austenite fraction acting as the austenite stabilizer. However, the morphology of the $\delta$-ferrite changed with the addition of copper, which created a difference between the two-phase structure at the high strain rate, and easily produced microcracks in the two-phase interface. A large number of ferrite islands are observed in the microstructure of the $2.42 \% \mathrm{Cu}-304 \mathrm{~L}$ steel in Figures $\mathbf{6 b}$ and $\mathbf{6 d}$. The measured kernel-average-misorientation (KAM) map and strain-contour map of the specimen at $1323 \mathrm{~K}$ and $5 \mathrm{~s}^{-1}$, for the strain of 0.69 are given in Figure 7. As shown, a small crack can be seen on the edge of the material. In the unbroken area, there are many long islands of ferrite, with a content of $10.8 \%$. The
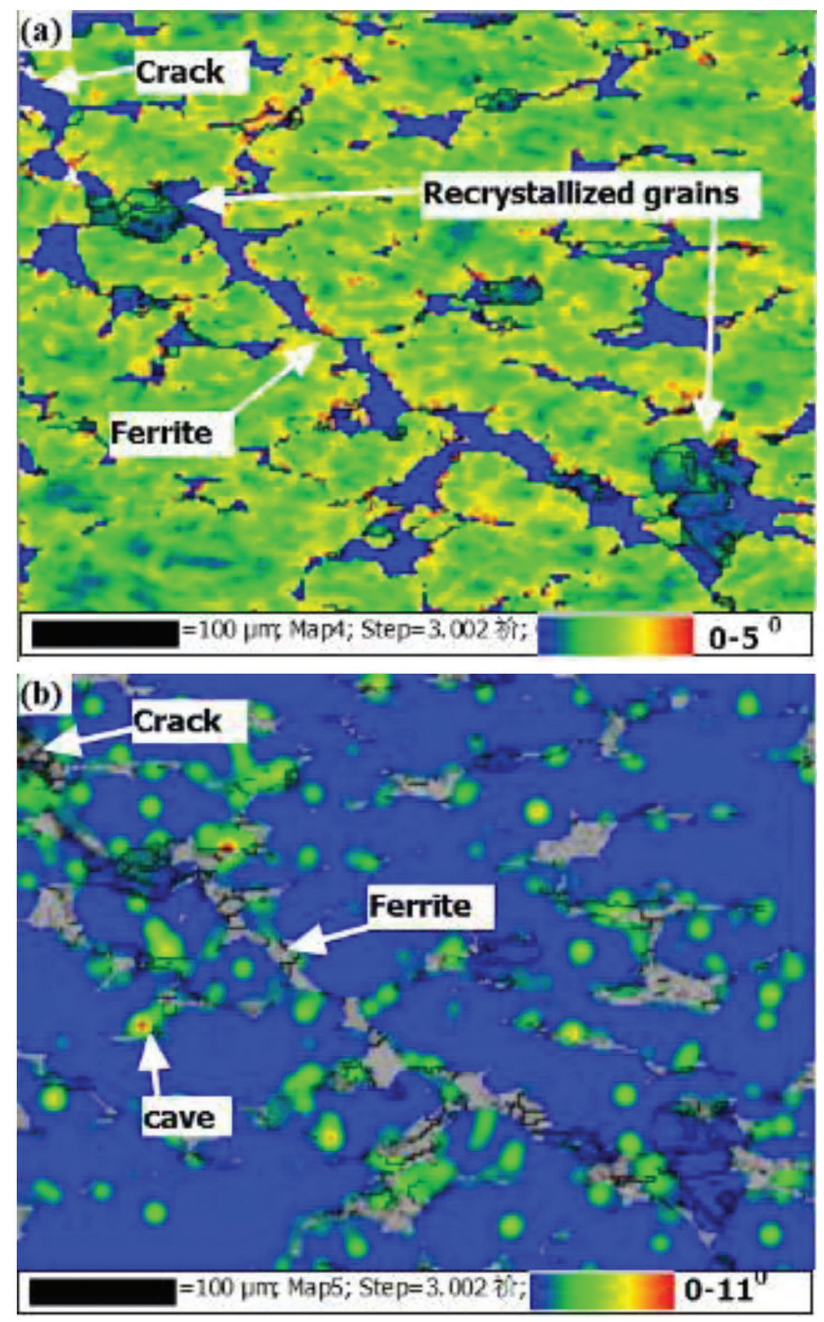

Figure 7: KAM and strain-contour maps of $2.42 \% \mathrm{Cu}-304 \mathrm{~L}$ steel at $1323 \mathrm{~K} / 5 \mathrm{~s}^{-1}$ 
average misorientation angle between $\delta$-ferrite and its nearest neighbor shows a significant change in color (Figure 7a). Some large strains appeared, owing to the deformation incompatibility between $\delta$-ferrite and the 304L matrix during the hot deformation. The straincontour maps show that stress is concentrated along with $\delta$-ferrite. It can be seen that some tips of $\delta$-ferrite display high stress concentrations (red dots in Figure 7b) leading to microcracking. With the increase in deformation, the stresses concentrated at the tips of $\delta$-ferrite facilitated the propagation of the microcracks from $\delta$-ferrite to the austenitic matrix. Moreover, dynamic recrystallization of fine grains takes place in the tips of $\delta$-ferrite, and dynamic recrystallization helps to prevent cracking.

Y. J. Dai ${ }^{23}$ pointed out that alloying elements dissolved into the structure, which changed the energy required for lattice faults per unit area. The addition of $\mathrm{Cu}$ increased the SFE and also increased the free energy of the entire system. Dynamic recrystallization takes place only when the energy exceeds the critical value. Moreover, copper also affects the hot-deformation activation energy $Q$. By comparing the data for the two kinds of steel from Table 2, it is clear that the hot-deformation activation energy decreases from $409 \mathrm{~kJ} / \mathrm{mol}$ to $376 \mathrm{~kJ} / \mathrm{mol}$. The storage capacity of $2.42 \% \mathrm{Cu}-304 \mathrm{~L}$ is decreased under the same deformation conditions, and the driving force is also reduced, which means that the material is not likely to undergo recrystallization. As shown in Figure 3, the recrystallization temperature increases. The recrystallization rate decreases at low rates and the softening process is slow. Also, at high strain rates, most of the curves indicate DRV. Hyejin Song ${ }^{22}$ also reported that a $\mathrm{Cu}$ addition causes a delay in the recrystallization due to the solute-drag effect.

Therefore, the above results indicate that the effect of the copper element on the hot behavior of the 304L stainless steel is detrimental to the occurrence of recrystallization and also makes a sample undergo hot brittle cracking.

\section{CONCLUSIONS}

In this work, the hot-deformation behaviors of the as-cast $304 \mathrm{~L}$ and $2.42 \% \mathrm{Cu}-304 \mathrm{~L}$ austenitic stainless steels were compared at temperatures of 1173-1423 K under strain rates of $0.01-20 \mathrm{~s}^{-1}$. Moreover, constitutive models and processing maps of the two kinds of steel were established. The following conclusions can be drawn from the results:

(1) The thermal effect and peak stress increased with an increase in the strain rate and a decrease in the deformation temperature. The following constitutive equations for the two materials were obtained:

$$
\dot{\varepsilon}=4.02 \times 10^{16}[\sinh (0.008 \sigma)]^{6.61} \exp \left(\frac{-408531.18}{R T}\right)
$$

$$
\dot{\varepsilon}=1.55 \times 10^{15}[\sinh (0.0089 \sigma)]^{5.67} \exp \left(\frac{-375650.43}{R T}\right)
$$

The peak-dissipation factor on the hot-processing map was located in the region of high temperature and low strain rate, and a sufficient dynamic recrystallization took place in this region. With the addition of copper, the unstable region at high temperature and low strain rate increased, and the processing range became narrower. The unstable region was dominated by adiabatic shear and local-flow instability. The optimal hot-working ranges for the $304 \mathrm{~L}$ and $2.42 \% \mathrm{Cu}-304 \mathrm{~L}$ steels were $1223-1423 \mathrm{~K} / 0.01-0.1 \mathrm{~s}^{-1}$ and $1273-1423 \mathrm{~K} / 0.01-0.05 \mathrm{~s}^{-1}$, respectively.

The addition of copper increased the stacking fault energy and reduced the hot-deformation activation energy, which was not conducive for the occurrence of recrystallization. At the same time, the addition of copper made the adiabatic-temperature rise more sensitive to the strain rate. Adiabatic-shear bands were formed at high rates. Copper also changed the $\delta$-ferrite morphology. All of these effects made the steel more prone to cracking.

\section{Acknowledgements}

The authors would like to thank the Provincial Special Fund for Coordinative Innovation Center of Taiyuan Heavy Machinery Equipment and Technology and Taiyuan Iron and Steel Co. Ltd. for providing the facilities for the experimental work. The project was supported by the National Key Research and Development Program of China (2016YFB0300205), the Joint Funds of the Coal Based and Low Carbon of Shanxi (U1510131) and the Science and Technology Major Project of Shanxi Province (MC2016-01).

\section{REFERENCES}

${ }^{1}$ R. Rana, V. Massardier, S. B. Singh, O. N. Mohanty, Effect of pretreatment on copper precipitation characteristics in a copper-alloyed interstitial free steel studied by thermoelectric power measurement, Metall. Mater. Trans. A, 44 (2013) 1, 186-200, doi:10.1007/s11661012-1386-Z

${ }^{2}$ I. T. Hong, C. H. Koo, Antibacterial properties corrosion resistance and mechanical properties of Cu-modified SUS 304 stainless steel, Mater. Sci. Eng., A, 393 (2005) 1-2, 213-222, doi:10.1016/j.msea. 2004.10.032

${ }^{3}$ M. Morcillo, I. Diaz, B. Chico, H. Cano, D. D. L. Fuente, Weathering steels: From empirical development to scientific design. A review, Corros. Sci., 83 (2014), 6-31, doi:10.1016/j.corsci. 2014.03.006

${ }^{4}$ S. W. Thompson, G. Krauss, Copper precipitation during continuous cooling and isothermal aging of A710-type steels, Metall. Mater. Trans. A, 27 (1996) 6, 1573-1579, doi:10.1007/ BF02649816

${ }^{5}$ L. Nan, K. Yang, Cu ions dissolution from $\mathrm{Cu}$-bearing antibacterial stainless steel, J. Mater. Sci. Technol., 26 (2010) 10, 941-944, doi:10.1016/S1005-0302(10)60152

${ }^{6}$ K. Shibata, S. J. Seo, M. Kaga et al., Suppression of surface hot shortness due to $\mathrm{Cu}$ in recycled steels, Mater. Trans., 43 (2002) 3 , 292-300, doi:10.2320/matertrans.43.292 


\section{J. LI et al.: EFFECT OF COPPER ELEMENT ON HOT BEHAVIOR OF 304L STAINLESS STEEL}

${ }^{7}$ L. G. Garza, C. J. V. Tyne, Surface hot-shortness of 1045 forging steel with residual copper, J. Mater. Process. Technol., 159 (2005) 2, 169-180, doi:10.1016/j.jmatprotec.2004.05.004

${ }^{8}$ C. R. Li, X. Yang, H. Wen, Study on enrichment rule of copper in steel surface during oxidation, Hot Working Technology, 39 (2010) 4, 8-11, doi:10.14158/j.cnki.1001-3814.2010.04.048

${ }^{9}$ A. Marchattiwar, A. Sarkar, J. K. Chakravartty, B. P. Kashyap, Dynamic recrystallization during hot deformation of 304 austenitic stainless steel, J. Mater. Eng. Perform., 22 (2013) 8, 2168-2175, doi:10.1007/s11665-013-0496-0

${ }^{10}$ F. Qin, H. Zhu, Z. Wang, X. Zhao, W. He, H. Chen, Dislocation and twinning mechanisms for dynamic recrystallization of as-cast mn18cr18n steel, Mater. Sci. Eng. A, 684 (2016), doi:10.1016/ j.msea.2016.12.095

${ }^{11}$ I. T. Hong, C. H. Koo, Antibacterial properties, corrosion resistance and mechanical properties of $\mathrm{Cu}$-modified SUS 304 stainless steel, Mater. Sci. Eng. A, 393 (2005) 1-2, 213-222, doi:10.1016/ j.msea.2004.10.032

${ }^{12}$ R. L. Goetz, S. L. Semiatin, The adiabatic correction factor for deformation heating during the uniaxial compression test, J. Mater. Eng. Perform., 10 (2001), 710-717, doi:10.1361/105994901770344593

${ }^{13}$ M. Mataya, V. Sackschewsky, Effect of internal heating during hot compression on the stress-strain behavior of alloy 304L, Metall. Mater. Trans. A, 25 (1994), 2737-2752, doi:10.1007/BF02649226

${ }^{14}$ H. J. Mcqueen, N. D. Ryan, Constitutive analysis in hot working, Mater. Sci. Eng. A, 322 (2002) 1, 43-63, doi:10.1016/S0921-5093 (01)01117-0

${ }^{15}$ Y. V. R. K. Prasad, Hot Working Guide: A compendium of processing maps, $2^{\text {nd }}$ ed., ASM International, 2015, 83
${ }^{16}$ Y. V. R. K. Prasad, H. L. Gegel, S. M. Doraivelu et al., Modeling of dynamic material behavior in hot deformation: Forging of Ti-6242, Metall. Trans. A, 15 (1984) 10, 1883-1892, doi:10.1007/ BF02664902

${ }^{17}$ Y. V. R. K. Prasad, T. Seshacharyulu, Processing maps for hot working of titanium alloys, Mater. Sci. Eng. A, 243 (1998) 1-2, 82-88, doi:10.1016/S0921-5093(97)00782-X

${ }^{18}$ K. Kishida, O. Akisue, Effect of copper content on mechanical properties of continuously annealed extra-low-carbon titanium-added steel sheets, Tetsu-to-Hagane, 76 (1990) 5, 759-766, doi:10.2355/ tetsutohagane1955.76.5_759

${ }^{19}$ T. S. Srivatsan, Physical properties of materials, Mater. Manuf. Process., 2 (2015) 30, 472-477, doi:10.1080/10426914. 2014.950075

${ }^{20}$ Y. Zhu, W. Zeng, Y. Zhao, Y. Shu, X. Zhang, Effect of processing parameters on hot deformation behavior and microstructural evolution during hot compression of Ti40 titanium alloy, Mater. Sci. Eng. A, 552 (2012) 2, 384-391, doi:10.1016/j.msea.2012.05.055

${ }^{21}$ L. Drozdová, B. Smetana, S. Zlá, V. Novák, M. Kawuloková, S. Rosypalová, P. Dostál, Study of phase transformation temperatures of alloys based on Fe-C-Cr in high-temperature area, J. Therm. Anal. Calorim., (2018), 1-8, doi:10.1007/ s10973-018-7012-6

${ }^{22}$ H. Song, J. Yoo, S. H. Kim, S. S. Sohn, M. Koo, N. J. Kim et al., Novel ultra-high-strength $\mathrm{Cu}$-containing medium-Mn duplex lightweight steels, Acta Mater., 135 (2017), doi:10.1016/ j.actamat.2017.06.035

${ }^{23}$ Y. J. Dai, M. I. Zhen-Li, T. Di, L. Jian-Chong, Effect of aluminium, copper and chromium on the stacking fault energy and mechanical properties of Fe-21mn-0.4c TWIP/TRIP steel, J. Iron Steel Res. Int., 23 (2011) 4, 32-34, doi:10.13228/j.boyuan.issn1001-0963.2011. 04.003 